\title{
Evaluarea fibrozei hepatice cu ajutorul tehnicilor FibroMax și FibroScan la pacienții cu hepatită cronică C
}

\author{
\begin{tabular}{c}
\hline Iulia Anca Marian (Deaconu)', Gheorghe Iulian Diaconescul,2, Valentin Cîrlig \\
${ }^{1}$ Spitalul Clinic de Boli Infecţioase şi Pneumoftiziologie „Victor Babeş“, Craiova, România \\
${ }^{2}$ Catedra de Boli Infecţioase, Universitatea de Medicină şi Farmacie, Craiova, România \\
${ }^{3}$ Catedra de Farmacologie, Universitatea de Medicină şi Farmacie, Craiova, România \\
\hline
\end{tabular}
}

\begin{abstract}
REZUMAT
Acest articol reprezintă un studiu asupra ultimelor metode de evaluare a fibrozei hepatice la pacienţii diagnosticaţi cu hepatită cronică C, analiza FibroMax şi dispozitivul FibroScan, incluzând evaluarea rezultatelor obţinute dar şi compararea şi corelarea lor. Lotul studiat a fost compus din 16 pacienţi diagnosticaţi şi trataţi în cadrul Spitalului Clinic de Boli Infecţioase şi Pneumoftiziologie „Victor Babeş“, Craiova, cu fibroză în grade variabile (F2-F4) şi inflamaţie de cauză virală (A0-A1 - A3). Rezultatele FibroScan au variat între 7,8 şi 66,4 $\mathrm{kPa}$. De asemenea, 11 din cei 16 pacienţi au avut o corespondenţă între rezultatul FibroTest (F) din cadrul analizei FibroMax şi rezultatul obţinut la FibroScan. Astfel, este ideal ca aceste două metode, deşi fiecare dintre ele având o mare importanţă, să fie folosite împreună pentru o cuantificare cât mai corectă a gradului de fibroză la pacienţii cu hepatită cronică C.
\end{abstract}

Cuvinte cheie: hepatită, FibroMax, FibroScan, fibroză

\section{INTRODUCERE}

Hepatita C este o boală infecțioasă cu afectare hepatică ce are ca agent determinant virusul hepatitic C (VHC). Acesta din urmă a fost descoperit de-a lungul anilor '80 în SUA de către cercetătorii din cadrul Departamentului Transfuzional al Institutului Național de Sănătate, care au constatat apariția, în urma transfuziilor, a unui virus hepatitic ce nu semăna nici cu virusul A, nici cu virusul B. Acesta se cantona la nivelul hepatocitului, determinând în prima fază inflamația parenchimului şi apoi fibroza şi necroza lui (1).

Evaluarea fibrozei hepatice se poate realiza cu ajutorul a trei tehnici principale: puncția-biopsie, utilizarea markerilor biologici (tehnica FibroMax) şi evaluarea FibroScan. Puncția biopsie reprezintă o tehnică invazivă prin care se prelevează mostre de țesut hepatic cu scopul evaluării histologice ale acestora. Deşi până acum câțiva ani realizarea aces- tei proceduri era obligatorie în diagnosticarea afectării hepatice de către virusurile B şi C, astăzi ea poate fi înlocuită cu succes de tehnici noninvazive (precum FibroMax şi FibroScan), reducându-se riscurile de sângerare, durere sau chiar şi riscul de deces prin stop respirator $(5,7,8)$.

\section{MATERIAL ŞI METODE}

În cadrul acestui articol, vom evalua rezultatele a 16 pacienţi diagnosticați cu hepatită cronică $C$, care au fost internați şi tratați în cadrul Clinicii de Adulţi II a Spitalului Clinic de Boli Infecţioase „Victor Babeş“ din Craiova. Toti pacienții acestui lot au efectuat atât analiza markerilor biologici FibroMax, cât şi evaluarea FibroScan.

Investigația FibroMax reprezintă o combinație a 5 teste noninvazive - FibroTest, ActiTest, SteatoTest, NashTest şi AshTest - şi se bazează pe un algoritm ce combină rezultatele determinărilor unor 
markeri biologici serici (alfa2-macroglobulina, apolipoproteina a1, haptoglobina, gamaglutamiltranspeptidaza - GGT, bilirubina totală, transaminazele hepatice - GOT şi GPT, colesterolul, trigliceridele şi glicemia bazală) cu vârsta, sexul, înălțimea şi greutatea pacientului, în scopul evaluării gradului de afectare hepatică (2).

FibroTestul sau indicele $\mathrm{F}$ al FibroMax-ului măsoară gradul fibrozei hepatice (corespunzând stadiilor F0-F4 din cadrul scorului METAVIR); ActiTest (A) măsoară gradul de inflamație în hepatitele cronice $\mathrm{B}$ sau C (corespunde stadiilor A0-A3 din cadrul scorului METAVIR); SteatoTest evaluează steatoza hepatică (corespunde stadiilor 0-3 de steatoză: S0-S3); Nashtestul evaluează steatohepatita non-alcoolică la pacienții cu dislipidemie, obezitate, diabet sau rezistență la insulină (corespunzând celor 3 grade din clasificarea Kleiner: N0- "not NASH", N1- "Borderline NASH" şi N2-"NASH"); AshTest măsoară gradul de afectare hepatică la pacienții consumatori cronici de alcool (corespunde gradelor H0-H3) (2).

FibroScanul reprezintă un dispozitiv ultramodern şi noninvaziv ce determină gradul de fibroză, precum şi stadiul de afectare hepatică. Acesta cuantifică fibroza hepatică bazându-se pe analiza deplasării unei unde elastice de şoc ce se propagă de-a lungul țesutului hepatic (3). Rezultatul este mediana a 10 măsurători valide şi se măsoară în $\mathrm{kPa}(\mathrm{cu}$ valori cuprinse între 2,5 şi $75 \mathrm{kPa}$ ). Interpretarea scorului se realizează astfel: valori $<7,1 \mathrm{kPa}$-fibroză absentă sau uşoară (F0-F1); valori cuprinse între 7,1 şi 9,5 kPa - fibroză F2; între 9,5 şi $13 \mathrm{kPa}$ - fi- broză F3; valori ce depăşesc 13 kPa - fibroză F4 (ciroza hepatică) (4). Această testare se poate realiza la recomandarea medicului sau la inițiativa pacientului, însă, în scopul stabilirii unui diagnostic corect, este recomandată efectuarea FibroScan alături de analiza markerilor FibroMax.

Astfel, am realizat o analiză a rezultatelor FibroMax ale celor 16 pacienți din lotul studiat, o corelație lineară între parametrii testați prin FibroMax şi rezultatele evaluării FibroScan, precum şi corelarea rezultatelor de la FibroTest (F) cu cele de la FibroScan.

\section{REZULTATE ŞI DISCUŢII}

În urma analizei rezultatelor în urma măsurătorilor FibroMax, am constatat că 10 dintre cei 16 pacienți studiați au obținut rezultate care îi încadrau în stadiul F4 al FibroTest (stadiul de ciroză hepatică), în timp ce doar 5 pacienți au prezentat un scor corespunzător F3 şi unul singur F2.

FibroTest

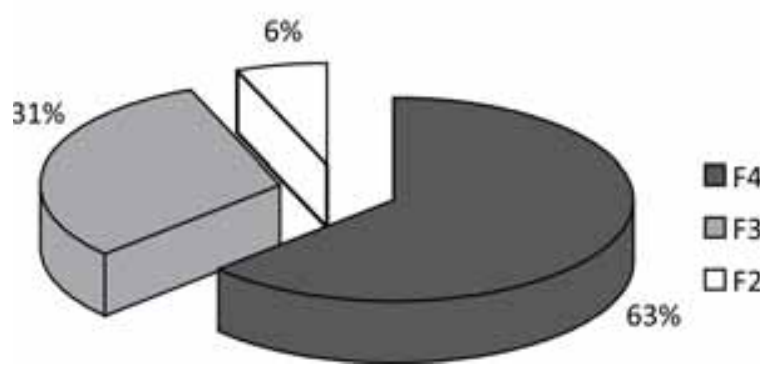

FIGURA 1. Stadiile de boală conform FibroTest

TABELUL 1. Rezultatele măsurătorilor FibroMax şi FibroScan ale pacienților lotului studiat

\begin{tabular}{|c|c|c|c|c|c|c|c|c|c|c|c|}
\hline \multirow{2}{*}{$\begin{array}{c}\text { Nr. } \\
\text { crt. }\end{array}$} & \multicolumn{2}{|c|}{ FibroTest (F) } & \multicolumn{2}{c|}{ ActiTest (A) } & \multicolumn{2}{c|}{ SteatoTest (S) } & \multicolumn{2}{c|}{ NashTest (N) } & \multicolumn{2}{c|}{ AshTest (H) } & Fibroscan \\
\hline 1 & Grad & Valoare & Grad & Valoare & Grad & Valoare & Grad & Valoare & Grad & Valoare & Valoare (kPa) \\
\hline 2 & 4 & 0,95 & 3 & 0,83 & 1 & 0,4 & 2 & 0,75 & 1 & 0,32 & 31,6 \\
\hline 3 & 2 & 0,85 & 3 & 0,65 & 2 & 0,63 & 1 & 0,5 & 0 & 0,17 & 7,8 \\
\hline 4 & 4 & 0,78 & 3 & 0,81 & 2 & 0,62 & 2 & 0,75 & 0 & 0,07 & 20 \\
\hline 5 & 4 & 0,94 & 2 & 0,53 & 0 & 0,28 & 0 & 0,25 & 0 & 0,05 & 15,1 \\
\hline 6 & 4 & 0,82 & 3 & 0,89 & 1 & 0,43 & 1 & 0,5 & 0 & 0 & 16,6 \\
\hline 7 & 3 & 0,6 & $0-1$ & 0,29 & 0 & 0,15 & 0 & 0,25 & 0 & 0,01 & 11,7 \\
\hline 8 & 4 & 0,82 & 3 & 0,76 & s1-s2 & 0,56 & 0 & 0,25 & 0 & 0,06 & 10,5 \\
\hline 9 & 4 & 0,8 & a1-a2 & 0,46 & s1-s2 & 0,52 & 2 & 0,75 & 0 & 0 & 13,6 \\
\hline 10 & 3 & 0,63 & 3 & 0,67 & 3 & 0,77 & 1 & 0,6 & 0 & 0,001 & 12,6 \\
\hline 11 & 4 & 0,88 & 2 & 0,55 & $0-1$ & 0,33 & 0 & 0,25 & 0 & 0,007 & 12,4 \\
\hline 12 & 3 & 0,66 & a1-a2 & 0,47 & 0 & 0,59 & 2 & 0,75 & 0 & 0,002 & 9,9 \\
\hline 13 & 4 & 0,81 & 3 & 0,74 & s1-s2 & 0,49 & 1 & 0,5 & 0 & 0,009 & 66,4 \\
\hline 14 & 3 & 0,61 & a1-a2 & 0,43 & 0 & 0,25 & 0 & 0,25 & 0 & 0,002 & 14,3 \\
\hline 15 & 4 & 0,77 & 3 & 0,62 & s1-s2 & 0,57 & 2 & 0,75 & 0 & 0,11 & 10,1 \\
\hline 16 & 3 & 0,63 & a1-a2 & 0,43 & 0 & 0,23 & 0 & 0,25 & 0 & 0,001 & 10,8 \\
\hline
\end{tabular}


În ceea ce priveşte rezultatele ActiTest, 56,25\% dintre pacienți (9) au prezentat valori corespunzătoare gradului A3 de inflamație, 12,5\% (2) s-au încadrat în gradul A2, în timp ce $25 \%$ (4) au fost la limita A1-A2 şi 6,25\% (1) la limita dintre A0 şi A1.

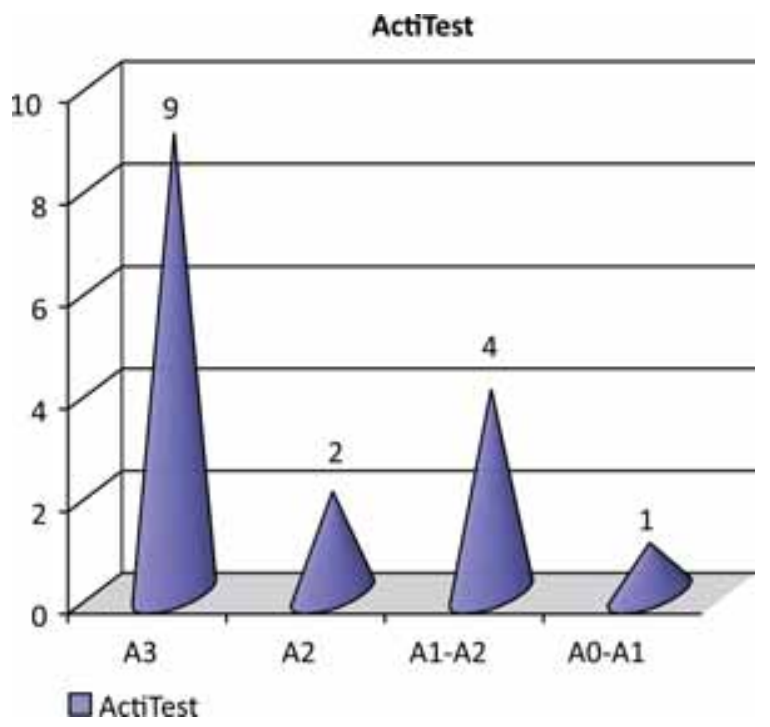

FIGURA 2. Rezultatele ActiTest

Rezultatele SteatoTest au fost: 5 pacienți cu steatoză S0, 2 pacienți la limita dintre S0 şi S1, 4 la limita S1-S2, 2 pacienți cu steatoză S1, 2 pacienți cu steatoză S2 şi un singur pacient cu steatoză avansată S3.

Scorurile NashTest indică o majoritate (7 pacienți) cu grad 0 (fără inflamație), 5 pacienți cu N2 şi, cei mai puțini, 4 pacienți, cu scor N1 (posibil NASH).

În ceea ce priveşte rezultatele testului Ash, o majoritate covârşitoare de 15 pacienți au avut scor 0 - fără inflamație hepatică datorată consumului de alcool şi un singur pacient s-a încadrat în H1 - inflamație hepatică (datorată consumului de alcool) moderată.

De asemenea, în cadrul acestui articol am calculat valoarea $\mathrm{r}$ a corelației lineare dintre valorile FibroTest şi cele FibroScan $(r=0,247)$, dintre valorile ActiTest şi cele FibroScan $(r=0,378)$, dintre cele obținute la SteatoTest şi FibroScan $(r=0,013)$, dintre cele ale NashTest şi FibroScan $(r=0,146)$, precum şi dintre valorile AshTest şi cele FibroScan $(\mathrm{r}=0,108)$.

De-a lungul analizei datelor obținute, am observat o corelație între gradul de fibroză $F$ şi valorile corespunzătoare aceluiaşi $\mathrm{F}$ obținute prin tehnica Fibroscan (reamintim că pentru un F0-F1 valorile trebuie să se mențină sub 7,1 kPa, F2 este cuprins între 7,1 şi 9,5 kPa, F3 între 9,5 şi $13 \mathrm{kPa}$ şi F4 trebuie să depăşească valoarea de $13 \mathrm{kPa}$ ). Astfel, în cazul a 11 dinrte cei 16 pacienți studiați, valorile FibroScan corespund cu gradul de fibroză calculat prin tehnica FibroMax.

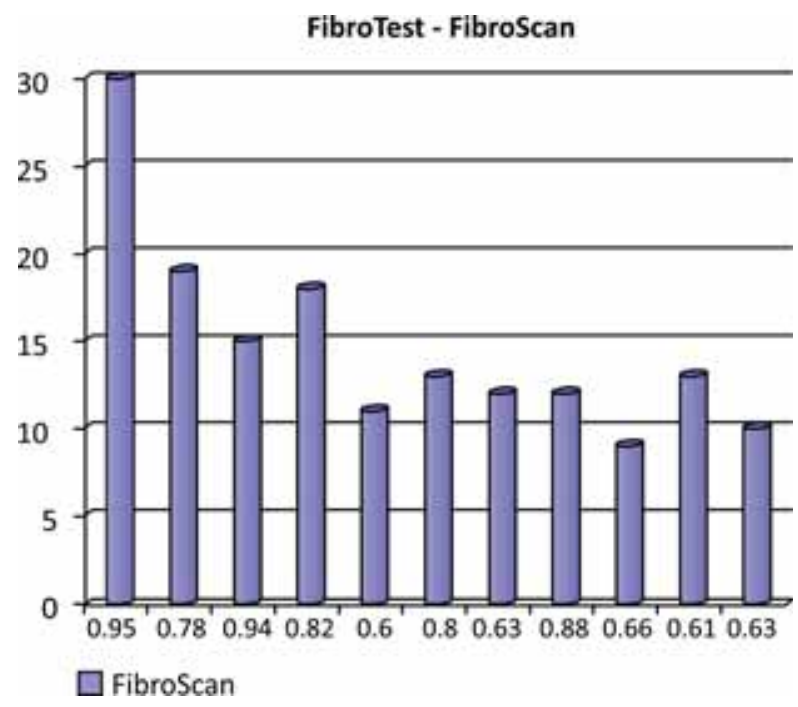

FIGURE 3. Corelațiile dintre FibroScan şi FibroTest

\section{CONCLUZII}

Hepatita cronică C contribuie la $25 \%$ până la $40 \%$ din totalul bolilor hepatice cronice şi reprezintă cauza a $40 \%$ din totalul transplanturilor hepatice (6).

Pacienții cu hepatită cronică $\mathrm{C}$ sunt depistați, în general, în intervalul de vârstă 30-50 ani, pe când pot avea deja grade diferite de fibroză hepatică (de la moderat până la avansat) (6).

Metodele de cuantificare a gradului fibrozei hepatice au tins spre înlocuirea celor invazive (precum puncția-biopsie hepatică) cu cele non-invazive, ultramoderne, precum testarea markerilor biologici din cadrul analizei FibroMax, dar şi evaluarea cu dispozitivul FibroScan (5).

În cadrul acestui articol s-a studiat un lot de 16 pacienți diagnosticați cu hepatită cronică C şi testați prin ambele metode, cu diverse grade de fibroză (de la F2 la F4) şi inflamație cauzată de virus (A0-A1 - A3) şi rezultate FibroScan cuprinse între $7,8 \mathrm{kPa}$ şi $66,4 \mathrm{kPa}$.

Calculând corelațiile valorilor obținute în urma celor două teste (valorile r), putem spune că cele două metode nu sunt neapărat comparabile, însă efectuarea ambelor este necesară în evaluarea corectă a fibrozei hepatice, dar şi în cazul includerii pacientului într-un program de tratament al hepatitei cronice. 